\title{
Synthesis and biological activity of $N^{a}-[4-[N-[(3,4-$ dihydro-2- methyl-4-oxo-6-quinazolinyl)methyl]- $N$-propargylamino]phenyl- acetyl]-L-glutamic acid $^{\star}$
}

\author{
Anna Kusakiewicz-Dawid ${ }^{1}$, Marta Bugaj ${ }^{1}$, Jolanta M. Dzik ${ }^{2}$, Barbara Gołos ${ }^{2}$, Patrycja \\ Wińska ${ }^{2}$, Krzysztof Pawełczak ${ }^{1}$, Barbara Rzeszotarska ${ }^{2}$ and Wojciech Rode ${ }^{2}$ \\ ${ }^{1}$ Institute of Chemistry, University of Opole, Opole, Poland, and ${ }^{2}$ Nencki Institute of \\ Experimental Biology, Polish Academy of Sciences, Warszawa, Poland
}

Received: 10 September, 2001; revised: 7 January, 2002; accepted: 2 February, 2002

Key words: thymidylate synthase, inhibition, ICI 198583 analogue

\begin{abstract}
2-Deamino-2-methyl- $N^{10}$-propargyl-5,8-dideazafolic acid (ICI 198583) is a potent inhibitor of thymidylate synthase. Its analogue, $N^{a}-[4-[N-[(3,4-d i h y d r o-2-m e t h y l-4-o x o-$ 6-quinazolinyl)methyl]- $N$-propargylamino]phenylacetyl]-L-glutamic acid, containing $p$-aminophenylacetic acid residue substituting $p$-aminobenzoic acid residue, was synthesized. The new analogue exhibited a moderately potent thymidylate synthase inhibition, of linear mixed type $v s$. the cofactor, $N^{5,10}$-methylenetetrahydrofolate. The $K_{\mathrm{i}}$ value of $0.34 \mu \mathrm{M}$, determined with a purified recombinant rat hepatoma enzyme, was about 30-fold higher than that reported for inhibition of thymidylate synthase from mouse leukemia L1210 cells by ICI 198583 (Hughes et al., 1990, J. Med. Chem. 33, $3060)$. Growth of mouse leukemia L5178Y cells was inhibited by the analogue $\left(\mathrm{IC}_{50}=\right.$ $1.26 \mathrm{mM}$ ) 180-fold weaker than by ICI $198583\left(\mathrm{IC}_{50}=6.9 \mu \mathrm{M}\right)$.
\end{abstract}

Thymidine 5'-monophosphate (TMP) which, metabolised to TTP, is essential for DNA replication and repair, is formed intracellularly de novo in a process of the C(5) methylation of 2 '-deoxyuridylate (dUMP), catalyzed by the enzyme thymidylate synthase (EC 2.1.1.45). The dUMP methylation reaction involves a concerted transfer and reduction of the one-carbon group (at the aldehyde oxidation level) of $N^{5,10}$-methylenetetrahydrofolate $\left(\mathrm{CH}_{2} \mathrm{H}_{4} \mathrm{PteGlu}\right)$, with concomitant production of thymidylate and dihydrofolate (Carreras \& Santi, 1995). Inhibition of thymidylate synthase by analogues of the nucleotide sub-

\footnotetext{
${ }^{\star}$ Presented at the 8th International Symposium on Molecular Aspects of Chemotherapy, September, 2001, Gdańsk, Poland.

${ }^{\circledR}$ Corresponding author: W. Rode, Nencki Institute of Experimental Biology, Pasteura 3, 02-093 Warszawa, Poland; e-mail address: rode@nencki.gov.pl
}

Abbreviations: DMF, N,N-dimethylformamide; DMTMM, 4-(5,6-dimethoxy-1,3,5-trazin-2-yl)-4-methylmorpholinium chloride; TFA, trifluoroacetic acid; THF, tetrahydrofuran. 
strate or pteridine cofactor is employed in anticancer, antiviral, antifungal and antiprotozoan chemotherapy (Heidelberger et al., 1983; Rathod, 1997; Georgopapadakou \& Walsh, 1996; Takemura \& Jackman, 1997).

The cofactor analogue, 2-deamino-2-methyl- $N^{10}$-propargyl-5,8-dideazafolic acid (ICI 198583; Fig. 1) is a potent inhibitor of thymidylate synthase (EC 2.1.1.45), a target in anticancer chemotherapy. In order to study the effect of insertion into ICI 198583 of a $\mathrm{CH}_{2}$ spacer between the phenyl and $\mathrm{CONH}$ moiety on interaction with thymidylate synthase, its analogue $N^{\alpha}$-[4-[N-[(3,4-dimethyl-2-methyl-4-oxo-6-quinazolinyl)methyl]-N-propargylamino]phenylacetyl]-L-glutamic acid (8; Fig. 2), containing a $p$-aminophenylacetic acid residue substituting the $p$-aminobenzoic acid residue, was synthesized and tested as an inhibitor of mammalian tumour thymidylate synthase. Cell growth inhibition by the new analogue was also studied.

\section{MATERIALS AND METHODS}

\section{Chemistry}

6-Bromomethyl-3,4-dihydro-2-methyl-4-oxyquinazoline (Hughes et al., 1990), 4-(4,6-dimethoxy-1,3,5-triazin-2-yl)-4-methylmorpholinium chloride (DMTMM) (Kunishima et al., 1999) and dimethyl glutamate hydrochloride (Greenstein \& Winitz, 1961) were synthesized as previously described. 4-Nitrophenylacetic acid was the Lancaster (\# 2577) product. Tetrahydrofuran, dioxane, diethyl ether and triethylamine were distilled over sodium and stored over sodium wire. DMF was azeotropically distilled and stored, similarly as DMA, over activated $\left(25^{\circ} \mathrm{C}\right) 4 \AA$ molecular sieves. The hydrogenolysis catalyst was $10 \%$ $\mathrm{Pd} / \mathrm{C}$ used at $20 \%$ of the substrate weight. Melting points were determined on a Boëtius heating block and are uncorrected. ${ }^{1} \mathrm{H}-\mathrm{NMR}$ spectra were determined using a Varian 500 $\mathrm{MHz}$ spectrometer. HPLC analyses were car- ried out using a Beckman System Gold chromatograph, a $5 \mu \mathrm{L}$ loop, an Alltech Alltima, $\mathrm{C}_{18} 5 \mu \mathrm{m}, 150 \times 4.6 \mathrm{~mm}$ column, detection at $210 \mathrm{~nm}$ and flow rate of $1 \mathrm{~mL} / \mathrm{min}$.

Dimethyl $\mathrm{N}^{\alpha}$-(4-nitrophenylacetyl)-L-glutamate (3). To a stirred for $10 \mathrm{~min}$ solution of 4-nitrophenylacetic acid $(0.724 \mathrm{~g}, 4 \mathrm{mmol})$, $\mathrm{HCl} \cdot \mathrm{Glu}(\mathrm{OMe})_{2}(0.848 \mathrm{~g}, 4 \mathrm{mmol})$ and $N$-methylmorpholine ( $440 \mu \mathrm{L}, 4 \mathrm{mmol})$ in THF (24 mL), DMTMM (1.218 g, $4 \mathrm{mmol}$ ) was added. After $3 \mathrm{~h}$ stirring at room temperature $\mathrm{N}$-methylmorpholine hydrochloride was filtered off and $\mathrm{H}_{2} \mathrm{O}(25 \mathrm{~mL})$ was added to the filtrate. The mixture was extracted with $\mathrm{Et}_{2} \mathrm{O}$ $(2 \times 20$ and $3 \times 30 \mathrm{~mL})$. The combined $\mathrm{Et}_{2} \mathrm{O}$ extracts were washed subsequently with saturated $\mathrm{Na}_{2} \mathrm{CO}_{3}(4 \times 20 \mathrm{~mL}), \mathrm{H}_{2} \mathrm{O}(2 \times 20 \mathrm{~mL})$, $2 \mathrm{M} \mathrm{HCl}(4 \times 20 \mathrm{~mL}), \mathrm{H}_{2} \mathrm{O}(2 \times 20 \mathrm{~mL})$ and brine, dried $\left(\mathrm{Na}_{2} \mathrm{SO}_{4}\right)$ and evaporated to give crude 3 as a colourless viscous oil that was crystallized from the mixture of $\mathrm{CH}_{2} \mathrm{Cl}_{2}$ /hexane: $0.738 \mathrm{~g} \mathrm{(55 \% );} \mathrm{mp.} 86-88^{\circ} \mathrm{C}$; HPLC $(0.1 \%$ TFA/ACN, 30:70) $t_{\mathrm{R}}=1.98$; purity $=94 \%$.

Dimethyl $\mathbf{N}^{\alpha}$-(4-aminophenylacetyl)-Lglutamate (4; Fig. 1). A solution of 3 (dimethyl $N^{\alpha}$-(4-nitrophenylacetyl)-L-glutamate; $1.36 \mathrm{~g}, 4 \mathrm{mmol})$ in $\mathrm{MeOH}(50 \mathrm{~mL})$, containing $10 \% \mathrm{Pd} / \mathrm{C}(0.272 \mathrm{~g})$ in suspension was stirred under hydrogen for $1.5 \mathrm{~h}$, whereupon TLC $\left(\mathrm{CHCl}_{3} / \mathrm{MeOH}, 9: 1\right)$ showed the absence of the starting material. The catalyst was removed by filtration and the filtrate evaporated to dryness giving a colourless oil that crystallized on standing: $1.227 \mathrm{~g}$ (99\%); white needles mp. $94-96^{\circ} \mathrm{C}$; HPLC monitoring (0.1\% TFA/ACN, $70: 30) t_{\mathrm{R}}=1.92$; purity $98 \%$.

Dimethyl N- ${ }^{\alpha}$ [4-(N-propargyl)phenylacetyll-L-glutamate (5; Fig. 1). A mixture of 4 (dimethyl $N^{\alpha}$-(4-aminophenylacetyl)-L-glutamate; $1.210 \mathrm{~g}, 4 \mathrm{mmol}), \mathrm{CaCO}_{3}(0.6 \mathrm{~g}, 6 \mathrm{mmol})$ and propargyl bromide $(0.64 \mathrm{~mL}, 8 \mathrm{mmol})$ in DMF $(15 \mathrm{~mL})$ was stirred in the dark at $20^{\circ} \mathrm{C}$ for $1.5 \mathrm{~h}$ with $\mathrm{TLC}$ monitoring $\left(\mathrm{CHCl}_{3} /\right.$ acetone, 9:1). Then, the mixture was poured into chloroform $(50 \mathrm{~mL})$, salts were filtered off, chloroform was evaporated and ethyl acetate $(100 \mathrm{~mL})$ was added. The organic phase was 
washed with $\mathrm{H}_{2} \mathrm{O}(7 \times 50 \mathrm{~mL})$ and brine $(50$ $\mathrm{mL}$ ), dried (over $\mathrm{Na}_{2} \mathrm{SO}_{4}$ ) and the solvent was removed in vacuo. The resulting orange oil (662 mg) was dissolved in chloroform (3 mL) and chromatographed on silica gel $(60 \mathrm{H}$, Merck Art. 7736) column [gel ( $25 \mathrm{~g}$ ); $4 \mathrm{~cm}$ i.d. $\times 6 \mathrm{~cm} \mathrm{l}$, which was eluted under low pressure with $\mathrm{CHCl}_{3}(50 \mathrm{~mL})$ and $\mathrm{CHCl}_{3}$ /acetone (9:1) (350 mL). Concentration of the appropriate fraction gave a yellow oil (350 mg, $25 \%$ ). HPLC monitoring (0.1\% TFA/ACN, 70:30); $t_{\mathrm{R}}=5.32$; purity $95 \%$.

Dimethyl $\mathbf{N}^{\alpha}-[4-[\mathrm{N}-[(3,4-d i h y d r o-2-m e-$ thyl-4-oxo-6-quinazolinyl)methyl]-N-prop argylamino]phenylacetyl]-L-glutamate (7;

Fig. 1). A mixture of $\mathbf{5}$ (dimethyl $N^{\alpha}$-[4-( $N$-propargyl)phenylacetyl]-L-glutamate; $0.350 \mathrm{~g}, 1 \mathrm{mmol}$ ), 6-bromomethyl-3,4-dihydro- 2-methyl-4-oxoquinazoline $(0.430 \mathrm{~g}, 1.7$ mmol) and $\mathrm{CaCO}_{3}(0.1 \mathrm{~g}, 1 \mathrm{mmol})$ in DMA (5 $\mathrm{ml}$ ) was stirred at $20^{\circ} \mathrm{C}$ in the dark for $24 \mathrm{~h}$ with TLC monitoring $\left(\mathrm{CHCl}_{3}\right.$ /acetone, 8:2). The inorganic salts were filtered off and the filtrate evaporated in vacuo; the resulting oil was dissolved in chloroform (5 mL) and chromatographed on silica gel $(60 \mathrm{H}$, Merck Art. 7736) column [gel ( $25 \mathrm{~g}) ; 4 \mathrm{~cm}$ i.d. $\times 6 \mathrm{~cm}$ 1], then eluted under low pressure with $\mathrm{CHCl}_{3}$ (50 mL) and subsequently with $\mathrm{CHCl}_{3}$ /acetone mixtures: 8:2 (400 mL), 7:3 (400 mL), 1:1 (200 mL), and 3:7 (450 mL). Concentration of the appropriate fraction gave an amorphous yellow solid: $0.380 \mathrm{~g}(73 \%), \mathrm{mp} .=208-210^{\circ} \mathrm{C}$, HPLC (0.1\% TFA/ACN, $70: 30) ; t_{\mathrm{R}}=8.97$; purity $95 \%$.

$\mathrm{N}^{\alpha}-[4-[\mathrm{N}-[(3,4-d i h y d r o-2-m e t h y l-4-o x o-6-$ quinazolinyl)methyl]-N-propargylamino]phenylacetyl]-L-glutamic acid (8; Fig. 1). The diester 7 [(dimethyl $N^{\alpha}$-[4-[N-[(3,4-dihydro-2-methyl-4-oxo-6-quinazolinyl)methyl]- $N$-propargylamino]phenylacetyl]-L-glutamate] $(0.153 \mathrm{~g}, 0.3 \mathrm{mmol})$ was treated with the mixture of $1 \mathrm{M} \mathrm{NaOH}(0.660 \mathrm{~mL})$ and $\mathrm{MeOH}$ $(6 \mathrm{~mL})$, to give immediately a clear yellow solution. Since the presence of starting material was shown after $2 \mathrm{~h}$ by TLC $\left(\mathrm{CHCl}_{3} / \mathrm{MeOH}\right.$, 9:1), further three portions of $1 \mathrm{M} \mathrm{NaOH} \mathrm{(3}$
$0.06 \mathrm{~mL}$ ) were added during $1.5 \mathrm{~h}$ and the mixture was stirred for $5.5 \mathrm{~h}, \mathrm{MeOH}$ was removed in vacuo and the residue was diluted with $\mathrm{H}_{2} \mathrm{O}$ ( $5 \mathrm{~mL})$. Addition of $1 \mathrm{M} \mathrm{HCl}(0.840 \mathrm{~mL})$ to $\mathrm{pH}$ 3.0 gave a gelatinous slightly yellow precipitate, which was washed with $\mathrm{H}_{2} \mathrm{O}(5 \mathrm{~mL})$ and dried under vacuum in the presence of $\mathrm{P}_{2} \mathrm{O}_{5}$ at $40^{\circ} \mathrm{C}$ for $12 \mathrm{~h}$. This gave $0.126 \mathrm{~g}(86 \%)$ of yellow solid $\mathrm{mp} .=190-191^{\circ} \mathrm{C}, \operatorname{HPLC}(0.1 \%$ TFA/ACN, 70:30): $t_{\mathrm{R}}=2.95$; purity $92 \%$.

\section{Biological studies}

Thymidylate synthase. Highly purified preparation of thymidylate synthases was obtained from $E$. coli-expressed rat hepatoma (Cieśla et al., 1995).

Enzyme assays. The $\left[5-{ }^{3} \mathrm{H}\right] \mathrm{dUMP}$ tritium release assay, performed as previously described (Rode et al., 1990), was used in inhibition studies.

Kinetic studies. To identify the type of inhibition involved, the effect of the new analogues on the dependence of reaction rate on $N^{5,10}$ methylenetetrahydrofolate concentration, in the form of Lineweaver-Burk plots, were analyzed as previously reported (Dąrowska et al., 1996) with the use of a program, based on nonlinear regression and designed for estimation of kinetic constants describing competitive (both linear and parabolic), noncompetitive, uncompetitive or mixed-type linear inhibitions. Results are presented as means \pm S.E.M. or means $\pm \%$ difference between the mean and each of two results, followed by the number of experiments $(\mathrm{N})$ in parentheses.

\section{RESULTS AND DISCUSSION}

$N^{\alpha}$-[4-[N-[(3,4-dihydro-2-methyl-4-oxo-6-quinazolinyl)methyl]- $N$-propargylamino]phenylacetyl]-L-glutamic acid (8; Fig. 1) was synthesized (Fig. 2) and its structure was confirmed by ${ }^{1} \mathrm{H}$ NMR (Table 1 ).

The new analogue was found to be a moderately potent thymidylate synthase inhibitor of 


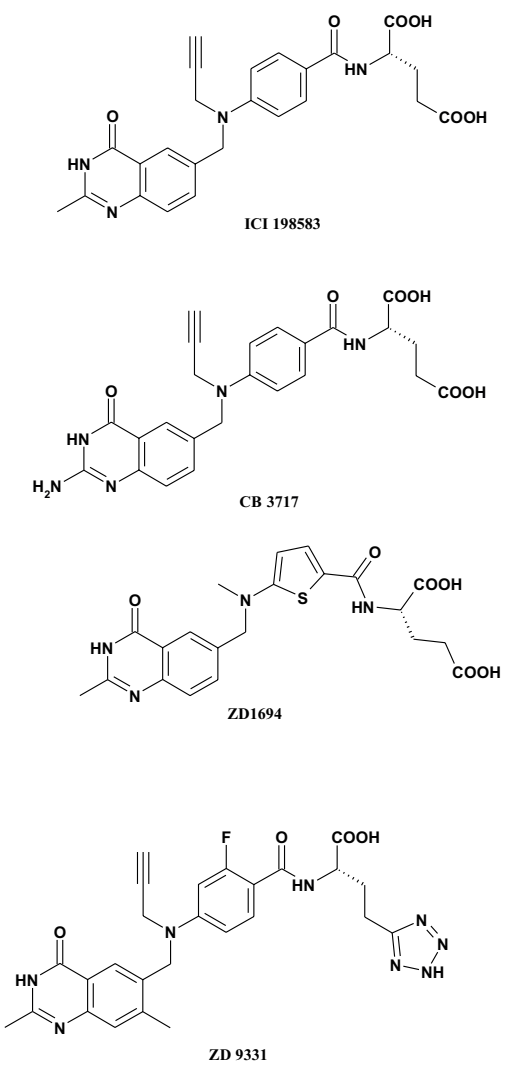

Figure 1. Structures of antifolates tested.

2-Desamino-2-methyl- $N^{10}$-propargyl-5,8-dideazafolate (ICI 198583), $N^{10}$-propargyl-5,8-dideazafolate (CB 3717), $N$-[5-[N-(3,4-dihydro-2-methyl-4-oxoquinazolin-6-ylmethyl)- $N$-methylamino]-2-thenoyl]-L-glutamic acid (ZD 1694; Tomudex; raltitrexed) and (2S)-2-\{o-fluoro- $p$-[ $N$ (2,7-dimethyl-4-oxo-3,4-dihydroquinazolin-6-ylmethyl)$N$-(prop-2-ynyl)amino]benzamido\}-4-(tetrazol-5-yl)butyric acid (ZD 9331).

linear mixed type $v s$. the cofactor, $N^{5,10}$-methylenetetrahydrofolate. The $K_{\mathrm{i}}$ value, determined with the purified recombinant rat hepatoma enzyme (Table 2), was 9-fold higher than that describing inhibition of the same enzyme by ICI 198583 (Table 2) and about 30-fold higher than that reported for L1210 thymidylate synthase inhibition by ICI 198583 (Hughes et al., 1990). On the other hand, the analogue was only 3 -fold less potent than (2S)-2-\{o-fluoro- $p$-[N-(2,7-dimethyl-4-oxo3,4-dihydroquinazolin-6-ylmethyl)- $N$-(prop2-ynyl)amino]benzamido\}-4-(tetrazol-5-yl)butyric acid (ZD 9331; Table 2). The newly synthesized analogue inhibited growth of mouse leukemia L5178Y cells 180-fold weaker than ICI 198583 (Table 2). However, it should be

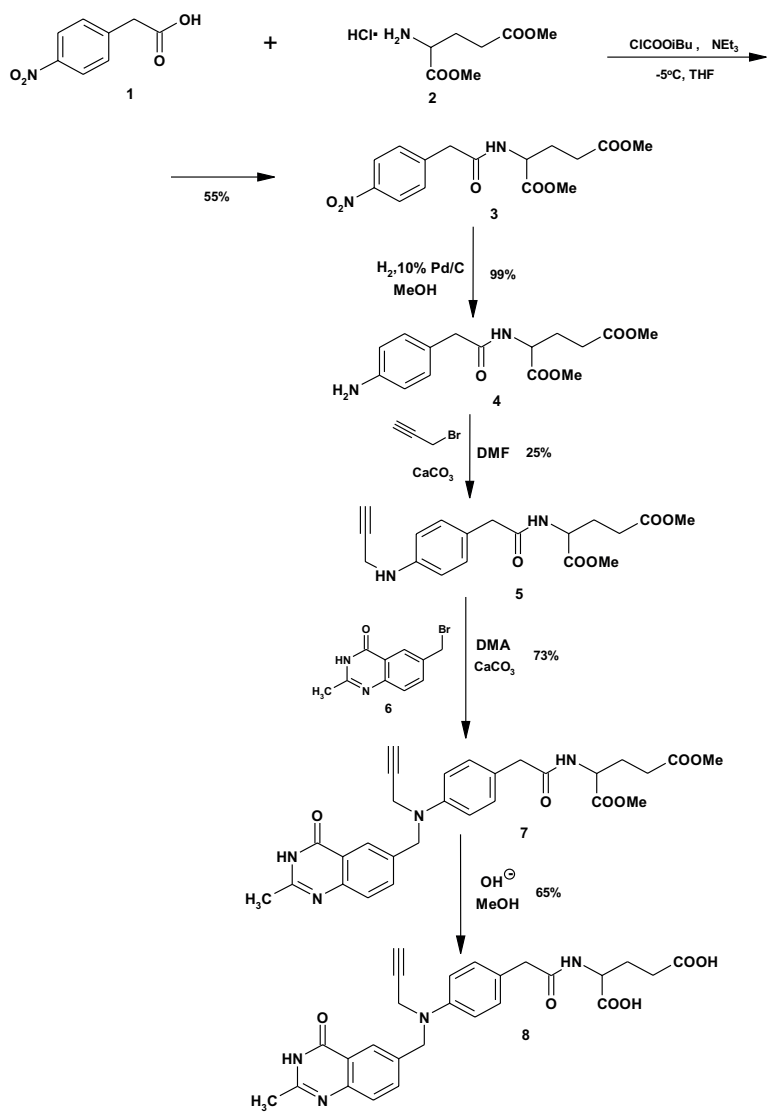

Figure 2. Synthesis of $N^{\alpha}$-[4-[N-[(3,4-dihydro-2methyl-4-oxo-6-quinazolinyl)methyl]- $N$-propargylamino]phenylacetyl]-L-glutamic acid (8).

noticed that L5178Y cells used in our experiments were 2-20-fold less sensitive than L1210 cells to growth inhibition by several known antifolates (Table 1; cf. Fig. 1), including ICI 198583, $N^{10}$-propargyl-5,8-dideazafolate (CB 3717), $N$-[5-[N-(3,4-dihydro-2-methyl-4-oxoquinazolin-6-ylmethyl)- $N$-methylamino]-2-thenoyl]-L-glutamic acid (ZD 1694; Tomudex; raltitrexed) and (2S)-2-\{o-fluoro- $p$ [N-(2,7-dimethyl-4-oxo-3,4-dihydroquinazolin-6-ylmethyl)- $N$-(prop-2-ynyl)amino]benzamido\}-4-(tetrazol-5-yl)butyric acid (ZD 9331).

Substitution of the $p$-aminobenzoic acid residue in ICI 198583 by $p$-aminophenylacetic acid residue resulted in a weaker inhibition of both cell growth and thymidylate synthase activity. Since inhibition of cell growth was influenced to a higher extent than inhibition of the enzyme, this may indicate a possible inter- 
Table 1. ${ }^{1} \mathrm{H}$ NMR analysis of $N^{\alpha}$-[4-[N-[(3,4-dihydro-2-methyl-4-oxo-6-quinazolinyl)methyl]- $N$-propargylamino]phenylacetyl]-L-glutamic acid (8) structure<smiles></smiles>

\begin{tabular}{|c|c|c|c|c|}
\hline${ }^{1}$ H Group & $\mathrm{S}^{1} \mathrm{H}$ & Peak multiplicities & $\delta[\mathrm{ppm}]$ & $J[\mathrm{~Hz}]$ \\
\hline $2\left(-\mathrm{CH}_{3}\right)$ & $3 \mathrm{H}$ & $\mathrm{s}$ & 2.332 & - \\
\hline 3 (-NH-) & $1 \mathrm{H}$ & $\mathrm{s}$ & 12.173 & - \\
\hline $5(-\mathrm{H})$ & $1 \mathrm{H}$ & $\mathrm{s}$ & 7.981 & - \\
\hline $7(-\mathrm{H})$ & $1 \mathrm{H}$ & $d$ & 7.694 & 8.24 \\
\hline $8(-\mathrm{H})$ & $1 \mathrm{H}$ & d & 7.536 & 7.33 \\
\hline $9\left(-\mathrm{CH}_{2}-\right)$ & $2 \mathrm{H}$ & $\mathrm{s}$ & 4.613 & - \\
\hline $11\left(-\mathrm{CH}_{2}\right)$ & $2 \mathrm{H}$ & $\mathrm{s}$ & 4.165 & - \\
\hline $13(\mathrm{CH} \equiv \mathrm{C}-)$ & $1 \mathrm{H}$ & $\mathrm{t}$ & 3.336 & - \\
\hline $3^{\prime}, 5^{\prime}(-\mathrm{H})$ & $2 \mathrm{H}$ & $d$ & 6.768 & 8.54 \\
\hline $2^{\prime}, 6^{\prime}(-\mathrm{H})$ & $2 \mathrm{H}$ & d & 7.071 & 8.55 \\
\hline $14\left(-\mathrm{CH}_{2}-\right)$ & $2 \mathrm{H}$ & $\mathrm{s}$ & 3.408 & - \\
\hline 16 (-NHCO-) & $1 \mathrm{H}$ & $d$ & 8.265 & 7.63 \\
\hline $17\left(-\mathrm{CH}^{\alpha}-\right)$ & $1 \mathrm{H}$ & $\mathrm{m}$ & 4.181 & - \\
\hline $18\left({ }^{\beta} \mathrm{CH}_{2}-\right)$ & $2 \mathrm{H}$ & $\mathrm{m}$ & 1.862 & \\
\hline $19\left({ }^{\gamma} \mathrm{CH}_{2}-\right)$ & $2 \mathrm{H}$ & $\mathrm{t}$ & 2.273 & \\
\hline $20,21(-\mathrm{COOH})$ & $2 \mathrm{H}$ & bs & 12.421 & \\
\hline
\end{tabular}

ference of the applied substitution with cellular uptake and/or polyglutamylation.

It should be mentioned that phenylacetyl analogues of folate (Roberts \& Shealy, 1973) and aminopterin (Montgomery et al., 1979) have been synthesized and tested against dihydrofolate reductase and cell growth. $\mathrm{A} \mathrm{CH}_{2}$ spacer inserted between the phenyl and CONH moiety caused a marked decrease in affinity of the enzyme for the new analogues, as compared with the parent compounds, but was much more detrimental to the potential of either phenylacetyl analogue to influence cell growth. In accord with the latter, the present results concerning the corresponding ana- logue of ICI 198583, pointed also to a much stronger influence of the structural alteration on cell growth than on the enzyme.

\section{R E F E R E N C E S}

Carreras, C.W. \& Santi, D.V. (1995) The catalytic mechanism and structure of thymidylate synthase. Ann. Rev. Biochem. 64, 721-762.

Cieśla, J., Weiner, K.X., Weiner, R.S., Reston, J.T., Maley, G.F. \& Maley, F. (1995) Isolation and expression of rat thymidylate synthase cDNA: Phylogenetic comparison with human 
Table 2. Inhibition of purified recombinant rat hepatoma thymidylate synthase and cell growth by the new analogue $N^{\alpha}$-[4-[N-[(3,4-dihydro-2-methyl-4-oxo-6-quinazolinyl)methyl]- $N$-propargylamino]phenylacetyl]-L-glutamic acid (8), parent 2-desamino-2-methyl- $N^{10}$-propargyl-5,8-dideazafolate (ICI 198583) and selected antifolates: $N^{10}$-propargyl-5,8-dideazafolate (CB 3717), $N$-[5-[N-(3,4-dihydro2-methyl-4-oxoquinazolin-6-ylmethyl)- $N$-methylamino]-2-thenoyl]-L-glutamic acid (ZD 1694; Tomudex; raltitrexed) and (2S)-2-\{o-fluoro-p-[N-(2,7-dimethyl-4-oxo-3,4-dihydroquinazolin-6-ylmethyl)- $N$-(prop-2-ynyl)amino]benzamido\}-4-(tetrazol-5-yl)butyric acid (ZD 9331).

Results are presented as means \pm S.E.M., or $\pm \%$ difference between the mean and each of two results, followed by the number of experiments $(\mathrm{N})$ in parentheses. Type of inhibition determined with $\mathrm{CH}_{2} \mathrm{H}_{4}$ PteGlu as a variable substrate.

\begin{tabular}{|c|c|c|c|c|}
\hline \multirow[t]{2}{*}{ Compound } & \multicolumn{2}{|c|}{ Thymidylate synthase inhibition } & \multicolumn{2}{|c|}{$\begin{array}{l}\text { Cell growth inhibition } \\
\mathrm{IC}_{50}(\mu \mathrm{M})\end{array}$} \\
\hline & $K_{\mathrm{i}}(\mu \mathrm{M})$ & Type of inhibition & L5178Y cells & L1210 cells \\
\hline 8 (ICI 198583 analogue) & $0.34 \pm 0.07(3)$ & Mixed $^{\mathrm{a}}$ & $1263 \pm 4 \%(2)$ & \\
\hline ICI 198583 & $0.039 \pm 0.01(3)$ & Comp. $^{\text {b }}$ & $6.9 \pm 7 \%(2)$ & $0.15^{\mathrm{c}}$ \\
\hline CB 3717 & $0.004 \pm 0.009 \%(2)$ & Mixed $^{\mathrm{a}}$ & $9.05 \pm 1.24(3)$ & $5.0^{\mathrm{d}}$ \\
\hline ZD 1694 & $0.029 \pm 0.008(3)^{\mathrm{e}}$ & Comp. $^{\text {b }}$ & $0.189 \pm 0.008(3)$ & $0.0088^{d}$ \\
\hline ZD 9331 & $0.13 \pm 12 \%(2)^{f}$ & Comp. $^{b}$ & $0.268 \pm 0.5 \%(2)$ & $0.02^{\mathrm{c}}$ \\
\hline
\end{tabular}

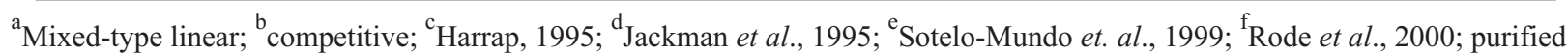
regenerating rat liver thymidylate synthase was used.

and mouse thymidylate synthases. Biochim. Biophys. Acta 1261, 233-242.

Dąbrowska, M., Zieliński, Z., Wranicz, M., Michalski, R., Pawełczak, K. \& Rode, W. (1996) Trichinella spiralis thymidylate synthase: Developmental pattern, isolation, molecular properties and inhibition by substrate and cofactor analogues. Biochem. Biophys. Res. Commun. 228, 440-445.

Georgopapadakou, N.H. \& Walsh, T.J. (1996) Antifungal agents: Chemotherapeutic targets and immunologic strategies. Antimicrob. Agents Chemother. 40, 279-291.

Greenstein, J.P. \& Winitz, M. (1961) Chemistry of Amino Acids; vol. 2, p. 934, Wiley, New York.

Harrap, K.R. (1995) Initiatives with platinum- and quinazoline-based antitumor molecules Fourteenth Bruce F. Cain memorial award lecture. Cancer Res. 55, 2761-2768.

Heidelberger, C., Danenberg, P.V. \& Moran, R.G. (1983) Fluorinated pyrimidines and their nucleosides. Adv. Enzymol. 54, 57-119.

Hughes, L.R., Jackman, A.L., Oldfield, J., Smith, R.C., Burrows, K.D., Marsham, P.R., Bishop, J.A.M., Jones, T.R., O’Connor, B.M. \& Calvert,
A.H. (1990) Quinazoline antifolate thymidylate synthase inhibitors: Alkyl, substituted alkyl, and aryl substituents in the $\mathrm{C} 2$ position. J. Med. Chem. 33, 3060-3067.

Jackman, A.L., Farrugia, D.C., Gibson, W., Kimbell, R., Harrap, K.R., Stephens, T.C., Azab, M. \& Boyle, F.T. (1995) ZD1694 (Tomudex): A new thymidylate synthase inhibitor with activity in colorectal cancer. Eur. J. Cancer 31A, 1277-1282.

Kunishima, M., Kawachi, C., Iwasaki, F., Terao, K. \& Tani, S. (1999) Synthesis and characterization of 4-(4,6-dimethoxy-1,3,5-triazin-2-yl)4-methylmorpholinium chloride. Tetrahedron Lett. 40, 5327-5330.

Montgomery, J.A., Piper, J.R., Elliot, R.D., Temple, C., Jr., Roberts, E.C. \& Shealy, Y.F. (1979) Analogues of methotrexate. J. Med. Chem. 22, 862-868.

Rathod, P.K. (1997) Antimalarial agents directed at thymidylate synthase. J. Pharm. Pharmacol. 49 (Suppl. 2), 704-711.

Roberts, E.C. \& Shealy, Y.F. (1973) Folic acid analogs. Modifications in the benzene-ring region. 3. Neohomofolic and neobishomofolic ac- 
ids. An improved synthesis method of folic acid and its analogs. J. Med. Chem. 16, 697-699.

Rode, W., Zieliński, Z., Dzik, J.M., Kulikowski, T., Bretner, M., Kierdaszuk, B., Cieśla, J. \& Shugar, D. (1990) Mechanism of inhibition of mammalian tumor and other thymidylate synthases by $N^{4}$-hydroxy-dCMP, $N^{4}$-hydroxy5-fluoro-dCMP, and related analogues. Biochemistry 29, 10835-10842.

Rode, W., Dąbrowska, M., Zieliński, Z., Gołos, B., Wranicz, M., Felczak, K. \& Kulikowski, T. (2000) Trichinella spiralis and Trichinella pseudospiralis: Developmental patterns of enzymes involved in thymidylate biosynthesis and pyrimidine salvage. Parasitology 120, 593-600.

Sotelo-Mundo, R.R., Cieśla, J., Dzik, J.M., Rode, W., Maley, F., Maley, G.F., Hardy, L.W. \& Montfort, W.R. (1999) Crystal structures of rat thymidylate synthase inhibited by Tomudex, a potent anticancer drug. Biochemistry 38, 1087-1094.

Takemura, Y. \& Jackman, A.L. (1997) Folate-based thymidylate synthase inhibitors in cancer chemotherapy. Anti-Cancer Drugs 8, 3-16. 